\title{
Effects of genetic variations in the Adiponectin pathway genes on the risk of colorectal cancer in the Chinese population
}

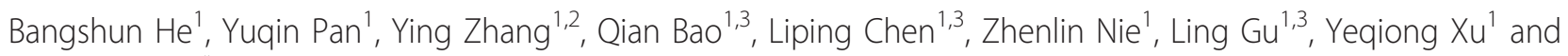
Shukui Wang ${ }^{1 *}$

\begin{abstract}
Background: Decreased expression of adiponectin (ADIPOQ) is associated with an increased risk for developing colorectal cancer (CRC) in humans. This study was designed to determine whether polymorphisms present in the ADIPOQ and its type 1 receptor (ADIPOR1) could affect the risk of CRC.

Methods: We measured five polymorphisms in the ADIPOQ and two polymorphisms in ADIPOR1, and analyzed their associations with CRC risk in 420 CRC patients and 555 age- and gender-matched healthy individuals.

Results: Multivariate logistic regression analyses revealed that the CRC risks (adjusted odds ratio and 95\% confidence interval) associated with the ADIPOR1 genotypes were $0.53(95 \% \mathrm{Cl}, 0.35-0.81)$ for $\mathrm{rs} 12733285 \mathrm{C} / \mathrm{T}, 0.59$ (95\% Cl, 0.45-0.78) for rs $1342387 \mathrm{~A} / \mathrm{G}$, and 0.59 (95\% Cl, 0.39-0.89) for rs1342387A/A, respectively. Furthermore, the risks were more significant in carriers of the allele A of rs $1342387 \mathrm{~A} / \mathrm{G}$ (adjusted OR, 0.59; 95\% Cl, 0.46-0.77) than noncarriers (G/G). In a further subgroup analysis, we observed that rs266729G/C was associated with an increased risk for colon cancer (adjusted OR, 1.50; 95\% Cl, 1.05-2.14) but not for rectal cancer (adjusted OR, 0.88; 95\% Cl, 0.631.22), and that carriers of the $\mathrm{G}$ allele had an increased risk for developing colon cancer (adjusted $\mathrm{OR}, 1.45 ; 95 \% \mathrm{Cl}$, 1.03-2.05).

Conclusions: We conclude that the $\mathrm{r}$ (12733285C/T genotype and the carriage of the A allele of $\mathrm{rs} 1342387$ (A/G or $\mathrm{A} / \mathrm{A}$ ) in $A D I P O R 1$ are the protective factors for CRC, while that rs266729G/C and G allele of ADIPOQ are the risk factors for colon cancer after excluding rectal cancer cases.
\end{abstract}

Keywords: Colorectal cancer, Polymorphism, ADIPOQ, ADIPOR, Genetic susceptibility

\section{Background}

Colorectal cancer (CRC) is one of the most common gastrointestinal tumors worldwide[1]. Epidemiological studies have demonstrated that some risk factors and interactions between genetic and environmental factors may play important roles in the pathogenesis of that cancer [2,3]. For example, individual genetic susceptibility is likely to play an important role in the development of some $35 \%$ of the CRC cases [4], suggesting that genetic background is one of the critical CRC risk factors $[5,6]$.

\footnotetext{
*Correspondence: shukwang@163.com

'The Central Laboratory of Nanjing First Hospital Affiliated to Nanjing

Medical University, Nanjing 210006, Jiangsu Province, China

Full list of author information is available at the end of the article
}

Many studies have demonstrated that obesity could increase the risk of cancer, including CRC [7-9]. In obese patients, adiponectin, a protein secreted by adipose tissue, has lower expression than that in non-obese subjects $[10,11]$, implying that decreased expression of adiponectin (ADIPOQ) may be associated with an increased risk for developing colorectal cancer (CRC) in humans [12-15]. Adiponectin and its receptors are expressed in colonic tissue [16]. For example, the expression of ADIPOR1 and ADIPOR2 are higher in colorectal carcinomas than in normal colonic epithelium [17]. Adiponectin seems to act in preneoplastic colonic lesions to regulate cell growth by activating, altering, or interacting with several pathways including leptin and $\mathrm{NF} \kappa \mathrm{B}$ pathway [18]. However, the opposite evidence has
Ciomed Central

() 2011 He et al; licensee BioMed Central Ltd. This is an Open Access article distributed under the terms of the Creative Commons Attribution License (http://creativecommons.org/licenses/by/2.0), which permits unrestricted use, distribution, and reproduction in any medium, provided the original work is properly cited. 
shown that adiponectin plasma levels are inversely associated with the risk of CRC [13], and that adiponectin can suppress the cell proliferation of colon cancer via AdipoR1- and -R2-mediated AMPK activation[19].

Several polymorphisms of adiponectin have been shown to affect adiponectin plasma levels[20,21]. Polymorphisms of the ligand (ADIPOQ,) and its type 1 receptor (ADIPOR1) are associated with the risk for insulin resistance, cardiovascular disease, and diabetes mellitus [20-26]. Polymorphisms of ADIPOR1 have been associated with the risk for cancers, probably by affecting adiponectin plasma levels [27-30]. Polymorphisms in the adiponectin gene have also been shown to correlate with adiponectin plasma levels, The genotypes rs266729 $\mathrm{C} / \mathrm{C}$, rs1501299 T/T, and rs2241766 G/G were respectively associated with decreased adiponectin plasma levels $[20,21]$, suggesting that these polymorphisms may be associated with increased risk of developing CRC. In a population-based case-control study, we genotyped seven polymorphisms of $A D I P O Q$ and ADIPOR1 genes to confirm such a hypothesis.

\section{Methods}

Four hundred and twenty inpatients who had been diagnosed histologically as CRC (colon cancer, $\mathrm{n}=191$, and rectum cancer, $n=229$ ) in Nanjing First hospital affiliated to Nanjing Medical University from January 2007 to January 2010 were recruited consecutively for this study. The case cohort ranged in age from 30 to 93 years (mean \pm SD, $62.9 \pm 12.3$ years). Five hundred and fifty five age-and gender-matched healthy individuals who came to hospital for routine health check were employed as non-cancer controls whose ages ranged from 44 to 91 years (mean \pm $\mathrm{SD}, 61.7 \pm 10.7$ years). Both case and control cohorts were from the same geographic region of Nanjing City, Jiangsu, China. For all CRC cases and control individuals, clinical characteristics of each subject, including smoking [Cumulative cigarette dose (pack-years) was calculated by the following formula: pack-years $=($ packs per day $) \times($ years smoked), those who had smoked at least once a day for $>1$ year in their lifetime were considered smokers, and nonsmokers were defined as ones who had stopped smoking at least 1 year before diagnosis in the patients and 1 year before the date signed on an informed consent for blood sample collection in the case of controls or who had never smoked in their lifetime.], drinking and related disease history (such as other cancer, diabetes and so on), was collected via a questionnaire designed in-house by the Department of Gastroenterology in the hospital. There was no significant difference in the demographic data between the two groups. This study protocol was approved by the Institutional Review Board of the hospital, and written informed consents were obtained from all participants.
Genomic DNA was extracted from peripheral blood mononuclear cells of CRC patients and controls using a E.Z.N.A. ${ }^{\circledR}$ SE Blood DNA Kit (Omega Bio-Tek, Inc, Norcross, GA, UAS) according to the manufacturer's instructions. Briefly, cells were lysed by a cell lysis solution and contaminated RNA in the samples was then removed by RNase A treatment and the protein was precipitated by the protein precipitation solution. The genomic DNA was finally precipitated by isopropanol, followed by being washed with $70 \%$ ethanol.

Polymerase chain reaction-restriction fragment length polymorphism (PCR-RFLP) was applied to detect the polymorphic sites of $A D I P O Q$ and ADIPOR1 as shown in Table 1. PCR amplification was performed in a $25 \mu \mathrm{L}$ reaction system consisting of $0.5 \mathrm{mmol} / \mathrm{L}$ of each primer, $4 \mathrm{mmol} / \mathrm{L}$ of $\mathrm{MgCl}_{2}, 1.25 \mathrm{U}$ of Ampli Taq Polymerase, and PCR buffer $(10 \mathrm{mmol} / \mathrm{L}$ of Tris- $\mathrm{HCl}, \mathrm{pH}$ $8.3 ; 50 \mathrm{mmol} / \mathrm{L}$ of $\mathrm{KCl})$. After the denaturation at $94^{\circ} \mathrm{C}$ 5 min, DNA amplification was achieved by 35 cycles of denaturing at $94^{\circ} \mathrm{C}$ for $30 \mathrm{sec}$, annealing at a certain temperature (as shown in Table 1) for $30 \mathrm{sec}$, extension at $72^{\circ} \mathrm{C}$ for $30 \mathrm{sec}$, and then followed by $72^{\circ} \mathrm{C}$ for $7 \mathrm{~min}$. For restriction enzyme digestion, $10 \mu \mathrm{L}$ PCR product was digested by $10 \mathrm{U}$ of Hin6I (MBI Fermentas, Vilnius, Lithuania) with buffer Tango for rs266729, Hinf I (MBI) with buffer B for rs822395, AvaI (MBI) with buffer Tango for rs2241766, NspI(MBI) with buffer Tango for rs1501299, and Nsi (MBI) with buffer R for rs12733285 in a final volume of $30 \mu \mathrm{L}$ and incubated at $37^{\circ} \mathrm{C}$ (Tru9 I with buffer $\mathrm{R}$ for rs822396 at $65^{\circ} \mathrm{C}$ ) overnight. Moreover, 10U BccI (New England Biolabs, Beverly, MA, USA) with NEBuffer 1 was utilized for digesting the 10 $\mu \mathrm{L}$ PCR product of rs1342387 in a final volume of 30 $\mu \mathrm{L}$ and incubated at $37^{\circ} \mathrm{C}$ overnight. Deoxyribonucleic acid fragments of rs266729, rs1342387 and rs822396 were separated by $3 \%$ agarose gel electrophoresis, and $4 \%$ agarose gel was used for the fragment of rs822395, rs2241766, rs2232853 and rs12733285. To validate the genotyping results, the genotyping experiments were repeated, a random selection of $10 \%$ of all samples was genotyped twice by direct sequence for quality control.

Statistical analysis of genotype distribution and allele frequencies was performed by using the $\chi 2$ test with SPSS 11.0 for Windows (SPSS, Chicago, IL). Odds ratios (OR) and 95\% confidence intervals (CIs) were calculated using a logistic regression model. Differences in mean values were evaluated using t-test. The $P$ value $<0.05$ was considered statistically significant.

\section{Results and Discussion}

Four hundred twenty patients with colorectal cancer and five hundred fifty and five healthy controls were evaluated in this population-based case-control association study, and there were no statistically significant 
Table 1 Primers and PCR conditions for genotype detection of ADIPOQ and ADIPOR1

\begin{tabular}{|c|c|c|c|c|c|c|c|}
\hline SNP & Gene & Position & $\begin{array}{c}\text { Annual } \\
\text { temperature }\end{array}$ & $\begin{array}{l}\text { Primer sequence } \\
\qquad\left(5^{\prime}-3^{\prime}\right)\end{array}$ & $\begin{array}{l}\text { Restriction } \\
\text { enzyme }\end{array}$ & $\begin{array}{c}\text { PCR-RFLP } \\
\text { products(bp) }\end{array}$ & Genotype \\
\hline rs266729 & $A D I P O Q$ & $\begin{array}{c}5^{\prime} \text { flanking }-11365 \\
\mathrm{C} \rightarrow \mathrm{G}\end{array}$ & $63^{\circ} \mathrm{C}$ & $\begin{array}{l}\text { GATGTCTTGTTGAAGTTGGTGCTG } \\
\text { TAGAAAGTITAGGCTTGAAGTGGC }\end{array}$ & Hin6I & $\begin{array}{c}176 \\
176,100,76 \\
100,76\end{array}$ & $\begin{array}{l}\mathrm{CC} \\
\mathrm{GC} \\
\mathrm{GG}\end{array}$ \\
\hline rs822395 & ADIPOQ & $\begin{array}{c}\text { Intron } 1-4034 \\
\quad A \rightarrow C\end{array}$ & $50^{\circ} \mathrm{C}$ & $\begin{array}{l}\text { TGATCGCACCTATTAGTGGAGgAAT* } \\
\text { TCCAGAATATGTGAAAGCCCCAGAG }\end{array}$ & Hinf I & $\begin{array}{c}208 \\
208,187,21 \\
187,21\end{array}$ & $\begin{array}{l}\text { AA } \\
\text { AC } \\
C C\end{array}$ \\
\hline rs822396 & ADIPOQ & $\begin{array}{c}\text { Intron } 1-3964 \\
\quad A \rightarrow G\end{array}$ & $58^{\circ} \mathrm{C}$ & $\begin{array}{l}\text { ATCAGAGTCCGTTCTTGGT } \\
\text { ACTGCTTGTCACCTCCACC }\end{array}$ & Tru9 I & $\begin{array}{c}458 \\
458,259,199 \\
259,199\end{array}$ & $\begin{array}{l}\text { GG } \\
\text { GA } \\
\mathrm{AA}\end{array}$ \\
\hline rs2241766 & ADIPOQ & Exon $2+45 \mathrm{~T} \rightarrow \mathrm{G}$ & $51^{\circ} \mathrm{C}$ & $\begin{array}{l}\text { GATCAAGGTGGGCTGCAATA } \\
\text { AGTCGTGGTITCCTGGTCAT }\end{array}$ & Ava I & $\begin{array}{c}246 \\
246,220,26 \\
220,26\end{array}$ & $\begin{array}{l}T 1 \\
\mathrm{TG} \\
\mathrm{GG}\end{array}$ \\
\hline rs1501299 & ADIPOQ & $\begin{array}{c}\text { Intron } 2+276 \\
G \rightarrow \top\end{array}$ & $50^{\circ} \mathrm{C}$ & $\begin{array}{l}\text { TCTAGGCCTTAGTTAATAATGCA* } \\
\text { CAGGAAACCACGACTCAAG }\end{array}$ & Nsp I & $\begin{array}{c}250 \\
250,230,20 \\
230,20\end{array}$ & $\begin{array}{l}\mathrm{AA} \\
\mathrm{AC} \\
\mathrm{CC}\end{array}$ \\
\hline rs12733285 & $A D I P O R 1$ & $\begin{array}{c}\text { Intron } 1-1742 \\
C \rightarrow T\end{array}$ & $66^{\circ} \mathrm{C}$ & $\begin{array}{l}\text { GTCATGCTATGCTCAACCCACAtGC* } \\
\text { CTTCCAGCTTCCTGTTCTCCTTAG }\end{array}$ & Nsi I & $\begin{array}{c}209 \\
209,183,26 \\
183,26\end{array}$ & $\begin{array}{l}C C \\
C T \\
T T\end{array}$ \\
\hline rs1342387 & $A D I P O R 1$ & $\begin{array}{c}\text { Intron } 4+5843 \\
\mathrm{G} \rightarrow \mathrm{A}\end{array}$ & $60^{\circ} \mathrm{C}$ & $\begin{array}{l}\text { CACCTGGTAGTGGGATTGG } \\
\text { GAGAAGCTGAGGCAGAGCA }\end{array}$ & $B C C I$ & $\begin{array}{c}474 \\
474,294,180 \\
294,180\end{array}$ & $\begin{array}{l}\text { GG } \\
A G \\
A A\end{array}$ \\
\hline
\end{tabular}

* Primers in lower case letters denote the mismatched position that is required for subsequent restriction digestion for the differentiation of the polymorphisms.

differences in their demographic data and clinical characteristics as summarized in Table 2.

The genotype distribution of the polymorphisms of $A D I P O Q$ and ADIPOR1 between the cases and controls are presented in Table 3. The observed frequencies of all tested genotypes and alleles in controls did not

Table 2 Demographic and clinical characteristics of CRC patients and the controls

\begin{tabular}{llll}
\hline Variables & Patients, $\mathbf{n}(\%)$ & Controls, $\mathbf{n}(\%)$ & $\begin{array}{l}\text { P- } \\
\text { value }\end{array}$ \\
\hline $\begin{array}{l}\text { Total cases } \\
\text { Gender }\end{array}$ & 420 & 555 & \\
$\quad$ Male & & & \\
$\quad$ Female & $280(66.67)$ & $339(61.08)$ & 0.084 \\
Age & $140(33.33)$ & $216(38.92)$ & \\
Mean \pm SD & & & \\
$\leq 60$ & $62.88 \pm 12.32$ & $61.71 \pm 10.65$ & 0.113 \\
$>60$ & $186(44.29)$ & $271(48.83)$ & 0.082 \\
Smoking status (Pack-year) & $234(55.71)$ & $284(51.17)$ & \\
Non-smoker & & & \\
Smoker & $316(73.24)$ & $406(73.15)$ & 0.508 \\
Alcohol consumption & $104(24.76)$ & $149(26.85)$ & \\
(year) & & & \\
Never & & & \\
$\leq 15$ & $274(65.24)$ & $379(68.29)$ & 0.514 \\
$>15$ & $119(28.33)$ & $139(25.05)$ & \\
Tumor site & $27(6.43)$ & $37(6.67)$ & \\
Colon & & & \\
Rectal & $191(45.48)$ & - & \\
\hline
\end{tabular}

derivate from the Hardy-Weinberg equilibrium. Logistic regression analysis revealed a significantly decreased risk (adjusted OR, 0.53; 95\% CI: 0.35-0.81) for the rs12733285 C/T heterozygote when compared with the rs12733285 C/C wild-type homozygote as shown in Table 3. Similarly, carriers of the A allele (rs1342387 A/ $\mathrm{G}$ or $\mathrm{A} / \mathrm{A}$ ) had decreased risk (adjusted OR 0.59; 95\% CI: 0.45-0.78, and adjusted OR 0.59; 95\% CI: 0.39-0.89, respectively) for CRC compared with noncarriers (i.e., rs1342387 G/G) as shown in Table 3, suggesting that carriers of the rs1342387 A allele had a significantly decreased risk for colorectal cancer (adjusted OR 0.59; 95\% CI: 0.46-0.77). In contrast, the distribution of the five polymorphisms (rs266729, rs822395, rs822396, rs1501766 and rs1501299) in ADIPOQ was not statistically significantly different between the case and control groups as shown in Table 3.

Subgroup analysis was performed based on the tumor site in this study, and logistic regression analysis revealed a significantly increased risk for the rs266729G/ $\mathrm{C}$ heterozygote (adjusted OR, 1.50; 95\% CI: 1.05-2.14) as compared with the rs266729 $\mathrm{C} / \mathrm{C}$ wild-type homozygote as shown in Table 4, suggesting that carriers of the $266729 \mathrm{G}$ allele had a significantly increased risk for colorectal cancer (adjusted OR 1.45; 95\% CI: 1.03-2.05). However, there was no difference in the genotype distribution between the sub-cohort of colon cancer and rectal cancer.

Through the population-based case-control study of 420 CRC patients and 555 age-and gender- matched 
Table 3 The genotype distribution of ADIPOQ and ADIPOR1 in CRC patients and controls

\begin{tabular}{|c|c|c|c|c|c|}
\hline Genotypes & Patients, n (\%) & Controls, n (\%) & OR $(95 \% \mathrm{Cl})^{\mathrm{a}}$ & OR $(95 \% \mathrm{Cl})^{\mathrm{b}}$ & $P$ value $^{c}$ \\
\hline \multicolumn{6}{|l|}{ rs266729 } \\
\hline $\mathrm{CC}$ & 173(41.79) & $243(43.78)$ & Reference & Reference & 0.705 \\
\hline GC & $205(48.81)$ & $261(47.03)$ & $1.10(0.84,1.44)$ & $1.12(0.85,1.46)$ & \\
\hline GG & $42(10.00)$ & 51(9.19) & $1.16(0.74,1.82)$ & $1.18(0.75,1.86)$ & \\
\hline GC/GG & $247(58.81)$ & $312(56.22)$ & $1.12(0.86,1.44)$ & $1.13(0.87,1.46)$ & \\
\hline \multicolumn{6}{|l|}{ rs822395 } \\
\hline $\mathrm{AA}$ & $343(81.67)$ & $440(79.28)$ & Reference & Reference & 0.38 \\
\hline$A C$ & $70(16.67)$ & 109(19.64) & $0.82(0.59,1.15)$ & $0.81(0.58,1.12)$ & \\
\hline CC & $7(1.67)$ & $6(1.08)$ & $1.50(0.50,4.49)$ & $1.47(0.49,4.46)$ & \\
\hline $\mathrm{AC} / \mathrm{CC}$ & 77(18.33) & $115(20.72)$ & $0.86(0.62,1.18)$ & $0.84(0.61,1.16)$ & \\
\hline \multicolumn{6}{|l|}{ rs822396 } \\
\hline $\mathrm{AA}$ & $344(81.90)$ & 450(81.08) & Reference & Reference & 0.82 \\
\hline$A G$ & 73(17.38) & $99(17.84)$ & $0.97(0.69,1.35)$ & $0.99(0.70,1.38)$ & \\
\hline GG & $3(0.71)$ & $6(1.08)$ & $0.65(0.16,2.63)$ & $0.63(0.16,2.54)$ & \\
\hline$A G / G G$ & 76(18.10) & 105(18.92) & $0.94(0.68,1.31)$ & $0.96(0.69,1.34)$ & \\
\hline \multicolumn{6}{|l|}{ rs2241766 } \\
\hline$\pi$ & $190(45.24)$ & 278(50.09) & Reference & Reference & 0.265 \\
\hline $\mathrm{TG}$ & 193(45.95) & 238(42.88) & $1.19(0.91,1.55)$ & $1.18(0.91,1.54)$ & \\
\hline GG & $37(8.81)$ & 39(7.03) & $1.39(0.85,2.26)$ & $1.42(0.86,2.32)$ & \\
\hline $\mathrm{TG} / \mathrm{GG}$ & $230(54.76)$ & 277(49.91) & $1.22(0.94,1.57)$ & $1.21(0.94,1.57)$ & \\
\hline \multicolumn{6}{|l|}{ rs1501299 } \\
\hline CC & $220(52.38)$ & $265(47.75)$ & Reference & Reference & 0.276 \\
\hline$A C$ & 160(38.10) & $224(40.36)$ & $0.86(0.66,1.13)$ & $0.87(0.66,1.15)$ & \\
\hline $\mathrm{AA}$ & $40(9.52)$ & 66(11.89) & $0.73(0.47,1.12)$ & $0.95(0.67,1.36)$ & \\
\hline$A C / A A$ & $200(47.62)$ & $290(52.25)$ & $0.83(0.65,1.07)$ & $0.84(0.65,1.09)$ & \\
\hline \multicolumn{6}{|l|}{ rs12733285 } \\
\hline CC & 386(91.90) & 477(85.95) & Reference & Reference & 0.004 \\
\hline CT & $34(8.10)$ & 78(14.05) & $0.54(0.35,0.82)$ & $0.53(0.35,0.81)$ & \\
\hline$\pi$ & $0(0.00)$ & $0(0.00)$ & - & - & \\
\hline $\mathrm{CT} / \mathrm{TT}$ & $34(8.10)$ & 78(14.05) & $0.54(0.35,0.82)$ & $0.53(0.35,0.81)$ & \\
\hline \multicolumn{6}{|l|}{ rs1342387 } \\
\hline GG & 213(50.71) & $210(37.84)$ & Reference & Reference & 0 \\
\hline$A G$ & 157(37.38) & 263(47.39) & $0.59(0.44,0.78)$ & $0.59(0.45,0.78)$ & \\
\hline $\mathrm{AA}$ & $50(11.90)$ & $82(14.77)$ & $0.60(0.40,0.90)$ & $0.59(0.39,0.89)$ & \\
\hline$A G / A A$ & 207(49.29) & $345(62.16)$ & $0.59(0.46,0.77)$ & $0.59(0.46,0.77)$ & \\
\hline
\end{tabular}

${ }^{a}$ Crude odds ratio

${ }^{\mathrm{b}}$ Age and gender adjusted odds ratio

${ }^{c} \chi^{2}$ test for all genotypes between the two groups

healthy controls in the Chinese population, we observed that CRC patients had lower frequency of rs $2733285 \mathrm{C} / \mathrm{T}$ and $\mathrm{rs} 1342387 \mathrm{~A} / \mathrm{G}$ or $\mathrm{A} / \mathrm{A}$ than healthy controls, and that carriers of the rs2733285T and rs1342387A allele had a significantly decreased risk for developing CRC. Moreover, we also revealed that rs266729G/C genotype and rs266729G allele was a risk factor for colon cancer.

It has been well known that obesity is one of the major risks for CRC [31,32] and that lack of physical exercise, diets with high sugar, refined grains, and low fiber are all believed as the risks of CRC [33-36]. Adiponectin is secreted by adipose tissue, and epidemic studies have demonstrated that its plasma levels were inversely correlated to BMI $[37,38]$. Recent studies have shown that polymorphism in ADIPOQ ( $\mathrm{rs} 2241766)$ is associated with the risk of breast cancer [27], and that a polymorphism rs266729 is associated with the risk of colorectal cancer [28]. However, in this case-control study, we failed to replicate the association between the two positive variants at $A D I P O Q$ (rs2241766, and rs266729) and CRC risk in Chinese population. Our findings are consistent with the studies reported in Czech [30] and British populations[39]. However, our subgroup analysis still revealed that $\mathrm{rs} 266729 \mathrm{G} / \mathrm{C}$ and 
Table 4 Genotype distribution in relation to sub sites in colorectal cancer

\begin{tabular}{|c|c|c|c|c|c|}
\hline \multirow[t]{2}{*}{ Genotypes } & \multirow{2}{*}{$\begin{array}{l}\text { controls } \\
\text { n (\%) }\end{array}$} & \multicolumn{2}{|c|}{ Colon cancer } & \multicolumn{2}{|c|}{ Rectal cancer } \\
\hline & & $\overline{\mathrm{n}(\%)}$ & OR(95\% Cl) & $n(\%)$ & OR $(95 \% \mathrm{CI})^{\mathrm{a}}$ \\
\hline \multicolumn{6}{|l|}{ rs266729 } \\
\hline $\mathrm{CC}$ & 243(43.78) & $68(35.60)$ & Reference & $105(45.85)$ & Reference \\
\hline GC & $261(47.03)$ & 107(56.02) & $1.50(1.05,2.14)$ & $98(42.79)$ & $0.88(0.63,1.22)$ \\
\hline GG & 51(9.19) & 16(8.38) & $1.19(0.64,2.25)$ & $26(11.35)$ & $1.20(0.71,2.04)$ \\
\hline GC/GG & $312(56.22)$ & $123(64.40)$ & $1.45(1.03,2.05)$ & $124(54.15)$ & $0.94(0.69,1.28)$ \\
\hline \multicolumn{6}{|l|}{ rs822395 } \\
\hline AA & $440(79.28)$ & 155(81.15) & Reference & 188(82.10) & Reference \\
\hline$A C$ & 109(19.64) & $32(16.75)$ & $0.82(0.53,1.27)$ & $38(16.59)$ & $0.80(0.53,1.20)$ \\
\hline $\mathrm{CC}$ & $6(1.08)$ & $4(2.09)$ & $1.63(0.45,5.97)$ & $3(1.31)$ & $1.25(0.31,5.06)$ \\
\hline $\mathrm{AC} / \mathrm{CC}$ & 115(20.72) & $36(18.85)$ & $0.86(0.56,1.31)$ & $41(17.90)$ & $0.82(0.55,1.22)$ \\
\hline \multicolumn{6}{|l|}{ rs822396 } \\
\hline AA & $450(81.08)$ & $161(84.29)$ & Reference & 183(79.91) & Reference \\
\hline$A G$ & $99(17.84)$ & $28(14.66)$ & $0.830(0.52,1.31)$ & $45(19.65)$ & $1.11(0.75,1.65)$ \\
\hline GG & $6(1.08)$ & $2(1.05)$ & $0.93(0.18,4.70)$ & $1(0.44)$ & $0.38(0.05,3.17)$ \\
\hline$A G / G G$ & 105(18.92) & $30(15.71)$ & $0.83(0.53,1.30)$ & 46(20.09) & $1.07(0.72,1.58)$ \\
\hline \multicolumn{6}{|l|}{ rs2241766 } \\
\hline$\pi$ & 278(50.09) & $91(47.64)$ & Reference & $99(42.23)$ & Reference \\
\hline $\mathrm{TG}$ & 238(42.88) & $87(45.55)$ & $1.10(0.78,1.56)$ & 106(46.29) & $1.25(0.90,1.72)$ \\
\hline GG & $39(7.03)$ & $13(6.81)$ & $1.07(0.54,2.11)$ & $24(10.48)$ & $1.71(0.97,3.01)$ \\
\hline $\mathrm{TG} / \mathrm{GG}$ & 277(49.91) & $100(52.36)$ & $1.10(0.79,1.53)$ & $130(56.77)$ & $1.31(0.96 .1 .79)$ \\
\hline \multicolumn{6}{|l|}{ rs1501299 } \\
\hline$C C$ & $265(47.75)$ & $97(50.79)$ & Reference & 123(53.71) & Reference \\
\hline$A C$ & $224(40.36)$ & $72(37.70)$ & $0.86(0.60,1.24)$ & $88(38.43)$ & $0.88(0.63,1.22)$ \\
\hline AA & 66(11.89) & $22(11.52)$ & $0.93(0.54,1.60)$ & 18(7.86) & $0.59(0.34,1.04)$ \\
\hline $\mathrm{AC} / \mathrm{AA}$ & $290(52.25)$ & $94(49.21)$ & $0.89(0.64,1.24)$ & 106(46.29) & $0.81(0.59,1.11)$ \\
\hline \multicolumn{6}{|l|}{ rs12733285 } \\
\hline $\mathrm{CC}$ & $477(85.95)$ & 175(91.62) & Reference & 211(92.14) & Reference \\
\hline $\mathrm{CT}$ & $78(14.05)$ & 16(8.38) & $0.51(0.29,0.91)$ & 18(7.86) & $0.51(0.30,0.88)$ \\
\hline$\pi$ & $0(0.00)$ & $0(0.00)$ & - & $0(0.00)$ & - \\
\hline $\mathrm{CT} / \mathrm{TT}$ & $78(14.05)$ & 16(8.38) & $0.51(0.29,0.91)$ & 18(7.86) & $0.51(0.30,0.88)$ \\
\hline \multicolumn{6}{|l|}{ rs1342387 } \\
\hline GG & $210(37.84)$ & 99(51.83) & Reference & 114(49.78) & Reference \\
\hline$A G$ & 263(47.39) & 69(36.13) & $0.57(0.40,0.81)$ & $88(38.43)$ & $0.62(0.45,0.87)$ \\
\hline AA & $82(14.77)$ & $23(12.04)$ & $0.54(0.32,0.93)$ & 27(11.79) & $0.66(0.40,1.09)$ \\
\hline $\mathrm{AG} / \mathrm{AA}$ & $345(62.16)$ & $92(48.17)$ & $0.57(0.41,0.79)$ & $115(50.22)$ & $0.62(0.46,0.85)$ \\
\hline
\end{tabular}

${ }^{a}$ Age and gender adjusted odds ratio

$266729 \mathrm{G}$ allele were risk factors for colon cancer but not for rectal cancer. These findings may partly explain the previous contradictive studies on the association between the polymorphism of rs2241766 and CRC risk [28]. Moreover, basic research had also predicted that $A D I P O Q$ and $A D I P O R$ have more potential effects on colon cancer than on rectal cancer [40], indicating that rs266729 G/C and $266729 \mathrm{G}$ allele were risk factors for colon cancer but not for rectal cancer, several studies have confirmed that polymorphisms $\mathrm{rs} 266729 \mathrm{C} / \mathrm{C}$, rs1501299 T/T and rs2241766 G/G in the ADIPOQ were associated with adiponectin plasma levels $[20,21,24]$. In particularly, such association were also deduced in Chinese population that G allele of rs266729 was significantly associated with lower adiponectin plasma levels[41], and that low levels of adiponectin was associated with the increased risk of CRC $[13,42]$.

The association between adiponectin type 1 receptor level and the two polymorphisms (rs12733285, rs1342387) in ADIPOR was still unclear. In this casecontrol study, the association between polymorphisms in ADIPOR1 (rs12733285, rs1342387) and CRC risk has also been investigated, and the results indicate that individuals with $\mathrm{rs} 12733285 \mathrm{C} / \mathrm{T}$ or $\mathrm{rs} 1342387 \mathrm{~A} / \mathrm{G}$ or $\mathrm{A} / \mathrm{A}$ had a decreased risk of CRC, which was similar with the finding in North American populations [28]. However, 
we have not observed the rs12733285T/T genotype both in case and control groups, in a sharp contrast with $15 \%$ of the rs12733285T/T genotype in North American population $[27,28]$. Nevertheless, our results are consistent with Hap-Map data among western Asian population http://www.hapmap.org/index.html.en. For polymorphism (rs1342387) of ADIPOR1, the distribution of genotypes in our studies was similar to the results by Wang et al [43]. Previous clinical studies have shown that the genotypes rs1342387A/G or A/A were associated with higher adiponectin plasma levels [21], and G/G genotype of rs1342387 of the ADIPOR1 gene was also associated with the indicators of obesity $[44,45]$. Therefore, the reason of the G/G genotype of rs1342387 as a risk factor for CRC may be correlated to obesity and insulin resistance. In addition, clinical studies have also revealed that adiponectin type 1 receptor is related to colorectal cancer progression[46]. However, the function of rs1342387 in ADIPOR1 remains unclear, and the direct relationship between rs1342387 and the risk of $\mathrm{CRC}$ needs to be further evaluated.

\section{Conclusions}

This case-control study demonstrates that polymorphisms in ADIPOR1 (rs12733285, rs1342387) are associated with the decreased risk of CRC, and polymorphism in ADIPOQ (rs266729) is a risk for colon cancer but not for rectal cancer.

\section{List of abbreviations}

ADIPOQ: adiponectin; CRC: colorectal cancer; ADIPOR1: adiponectin type 1 receptor (); OR: odds ratio; $\mathrm{Cl}$ : confidence interval

\section{Acknowledgements and Funding \\ This project was supported by a grant (2008-86, to SKW) from The Personne Ministry of China, a grant (08NMUM107, to BSH) from the Technology Development Program of Nanjing Medical University, Jiangsu Province, China, and a grant from Social Development Technology Projects of Kunshan City, China (KS1013, to YZ). \\ We appreciate Prof. Hong-Guang Xie, Central Laboratory, Nanjing First Hospital, Nanjing Medical University, Jiangsu, China, for his critical review} and scientific editing of the manuscript and constructive comments.

\section{Author details \\ ${ }^{1}$ The Central Laboratory of Nanjing First Hospital Affiliated to Nanjing Medical University, Nanjing 210006, Jiangsu Province, China. ${ }^{2}$ Clinical Laboratory, Traditional Chinese Medicine Hospital of Kunshan, Kunshan 215300, Jiangsu Province, China. ${ }^{3}$ Department of Life Sciences, Nanjing Normal University, Nanjing 210046, Jiangsu Province, China.}

\section{Authors' contributions}

$B H, Y Z, Q B$ participated in the genotype detection of samples. LC, ZN, LG and $Y X$ collected the samples and clinical characteristics of each subject. $\mathrm{BH}$ and YP designed the study and performed the statistical analysis and involved in drafting the manuscript or revising it critically for important intellectual content, SW conceived of the study, and participated in its design and coordination. All authors read and approved the final manuscript.

\section{Competing interests}

The authors declare that they have no competing interests.
Received: 20 December 2010 Accepted: 12 July 2011

Published: 12 July 2011

\section{References}

1. Peto J: Cancer epidemiology in the last century and the next decade. Nature 2001, 411:390-395.

2. Fearon ER: Human cancer syndromes: clues to the origin and nature of cancer. Science 1997, 278:1043-1050.

3. Risch N: The genetic epidemiology of cancer: interpreting family and twin studies and their implications for molecular genetic approaches. Cancer Epidemiol Biomarkers Prev 2001, 10:733-741.

4. Lichtenstein P, Holm NV, Verkasalo PK, Iliadou A, Kaprio J, Koskenvuo M, Pukkala E, Skytthe A, Hemminki K: Environmental and heritable factors in the causation of cancer-analyses of cohorts of twins from Sweden, Denmark, and Finland. N Engl J Med 2000, 343:78-85.

5. Strate LL, Syngal S: Hereditary colorectal cancer syndromes. Cancer Causes Control 2005, 16:201-213.

6. de la Chapelle A: Genetic predisposition to colorectal cancer. Nat Rev Cancer 2004, 4:769-780.

7. Calle EE, Kaaks R: Overweight, obesity and cancer: epidemiological evidence and proposed mechanisms. Nat Rev Cancer 2004, 4:579-591.

8. Le Marchand L, Wilkens LR, Kolonel LN, Hankin JH, Lyu LC: Associations of sedentary lifestyle, obesity, smoking, alcohol use, and diabetes with the risk of colorectal cancer. Cancer Res 1997, 57:4787-4794.

9. Oxentenko AS, Bardia A, Vierkant RA, Wang AH, Anderson KE, Campbell PT, Sellers TA, Folsom AR, Cerhan JR, Limburg PJ: Body size and incident colorectal cancer: a prospective study of older women. Cancer Prev Res (Phila) 2010, 3:1608-1620.

10. Ouchi N, Kihara S, Arita Y, Maeda K, Kuriyama H, Okamoto Y, Hotta K, Nishida M, Takahashi M, Nakamura T, Yamashita S, Funahashi T, Matsuzawa Y: Novel modulator for endothelial adhesion molecules: adipocyte-derived plasma protein adiponectin. Circulation 1999, 100:2473-2476.

11. Meilleur KG, Doumatey A, Huang H, Charles B, Chen G, Zhou J, Shriner D, Adeyemo A, Rotimi C: Circulating adiponectin is associated with obesity and serum lipids in West Africans. J Clin Endocrinol Metab 2010, 95:3517-3521.

12. Barresi $V$, Tuccari G, Barresi G: Adiponectin immunohistochemical expression in colorectal cancer and its correlation with histological grade and tumour microvessel density. Pathology 2009, 41:533-538.

13. Wei EK, Giovannucci E, Fuchs CS, Willett WC, Mantzoros CS: Low plasma adiponectin levels and risk of colorectal cancer in men: a prospective study. J Natl Cancer Inst 2005, 97:1688-1694.

14. Otake S, Takeda H, Fujishima S, Fukui T, Orii T, Sato T, Sasaki Y, Nishise S, Kawata S: Decreased levels of plasma adiponectin associated with increased risk of colorectal cancer. World J Gastroenterol 2010, 16:1252-1257.

15. Nakajima TE, Yamada Y, Hamano T, Furuta K, Matsuda T, Fujita S, Kato K, Hamaguchi T, Shimada Y: Adipocytokines as new promising markers of colorectal tumors: adiponectin for colorectal adenoma, and resistin and visfatin for colorectal cancer. Cancer Sci 2010, 101:1286-1291.

16. Byeon JS, Jeong JY, Kim MJ, Lee SM, Nam WH, Myung SJ, Kim JG, Yang SK, $\mathrm{Kim} \mathrm{JH}$, Suh DJ: Adiponectin and adiponectin receptor in relation to colorectal cancer progression. Int J Cancer 2010.

17. Williams CJ, Mitsiades N, Sozopoulos E, Hsi A, Wolk A, Nifli AP, TseleniBalafouta S, Mantzoros CS: Adiponectin receptor expression is elevated in colorectal carcinomas but not in gastrointestinal stromal tumors. Endocr Relat Cancer 2008, 15:289-299.

18. Fenton Jl, Birmingham JM, Hursting SD, Hord NG: Adiponectin blocks multiple signaling cascades associated with leptin-induced cell proliferation in Apc Min/+ colon epithelial cells. Int J Cancer 2008 122:2437-2445.

19. Kim AY, Lee YS, Kim KH, Lee JH, Lee HK, Jang SH, Kim SE, Lee GY, Lee JW, Jung SA, Chung HY, Jeong S, Kim JB: Adiponectin represses colon cancer cell proliferation via AdipoR1- and -R2-mediated AMPK activation. Mol Endocrinol 2010, 24:1441-1452.

20. Qi L, Doria A, Manson JE, Meigs JB, Hunter D, Mantzoros CS, Hu FB: Adiponectin genetic variability, plasma adiponectin, and cardiovascular risk in patients with type 2 diabetes. Diabetes 2006, 55:1512-1516.

21. Heid IM, Wagner SA, Gohlke H, Iglseder B, Mueller JC, Cip P, Ladurner G, Reiter R, Stadlmayr A, Mackevics V, Illig T, Kronenberg F, Paulweber B: 
Genetic architecture of the APM1 gene and its influence on adiponectin plasma levels and parameters of the metabolic syndrome in 1,727 healthy Caucasians. Diabetes 2006, 55:375-384.

22. Filippi E, Sentinelli F, Romeo S, Arca M, Berni A, Tiberti C, Verrienti A, Fanelli M, Fallarino M, Sorropago G, Baroni MG: The adiponectin gene SNP $+276 \mathrm{G}>\mathrm{T}$ associates with early-onset coronary artery disease and with lower levels of adiponectin in younger coronary artery disease patients (age <or $=50$ years). J Mol Med 2005, 83:711-719.

23. Hara K, Boutin P, Mori Y, Tobe K, Dina C, Yasuda K, Yamauchi T, Otabe $S$, Okada T, Eto K, Kadowaki H, Hagura R, Akanuma Y, Yazaki Y, Nagai R, Taniyama M, Matsubara K, Yoda M, Nakano Y, Tomita M, Kimura S, Ito C, Froguel P, Kadowaki T: Genetic variation in the gene encoding adiponectin is associated with an increased risk of type 2 diabetes in the Japanese population. Diabetes 2002, 51:536-540.

24. Menzaghi C, Ercolino T, Di Paola R, Berg AH, Warram JH, Scherer PE, Trischitta V, Doria A: A haplotype at the adiponectin locus is associated with obesity and other features of the insulin resistance syndrome. Diabetes 2002, 51:2306-2312.

25. Soccio T, Zhang YY, Bacci S, Mlynarski W, Placha G, Raggio G, Di Paola R, Marucci A, Johnstone MT, Gervino EV, Abumrad NA, Klein S, Trischitta V, Doria A: Common haplotypes at the adiponectin receptor 1 (ADIPOR1) locus are associated with increased risk of coronary artery disease in type 2 diabetes. Diabetes 2006, 55:2763-2770.

26. Vasseur F, Helbecque N, Dina C, Lobbens S, Delannoy V, Gaget S, Boutin P, Vaxillaire M, Lepretre F, Dupont S, Hara K, Clément K, Bihain B, Kadowaki T, Froguel P: Single-nucleotide polymorphism haplotypes in the both proximal promoter and exon 3 of the APM1 gene modulate adipocytesecreted adiponectin hormone levels and contribute to the genetic risk for type 2 diabetes in French Caucasians. Hum Mol Genet 2002 11:2607-2614

27. Kaklamani VG, Sadim M, Hsi A, Offit K, Oddoux C, Ostrer H, Ahsan H, Pasche $B$, Mantzoros $C$ : Variants of the adiponectin and adiponectin receptor 1 genes and breast cancer risk. Cancer Res 2008, 68:3178-3184.

28. Kaklamani VG, Wisinski KB, Sadim M, Gulden C, Do A, Offit K, Baron JA, Ahsan H, Mantzoros C, Pasche B: Variants of the adiponectin (ADIPOQ) and adiponectin receptor 1 (ADIPOR1) genes and colorectal cancer risk. JAMA 2008, 300:1523-1531.

29. Moore SC, Leitzmann MF, Albanes D, Weinstein SJ, Snyder K, Virtamo J, Ahn J, Mayne ST, Yu H, Peters U, Gunter MJ: Adipokine genes and prostate cancer risk. Int J Cancer 2009, 124:869-876.

30. Pechlivanis S, Bermejo JL, Pardini B, Naccarati A, Vodickova L, Novotny J, Hemminki K, Vodicka P, Forsti A: Genetic variation in adipokine genes and risk of colorectal cancer. Eur J Endocrinol 2009, 160:933-940.

31. Dai Z, Xu YC, Niu L: Obesity and colorectal cancer risk: a meta-analysis of cohort studies. World J Gastroenterol 2007, 13:4199-4206.

32. Moghaddam AA, Woodward M, Huxley R: Obesity and risk of colorectal cancer: a meta-analysis of 31 studies with 70,000 events. Cancer Epidemiol Biomarkers Prev 2007, 16:2533-2547.

33. Potter JD, Slattery ML, Bostick RM, Gapstur SM: Colon cancer: a review of the epidemiology. Epidemiol Rev 1993, 15:499-545.

34. Chao A, Connell CJ, Jacobs EJ, McCullough ML, Patel AV, Calle EE, Cokkinides VE, Thun MJ: Amount, type, and timing of recreational physical activity in relation to colon and rectal cancer in older adults: the Cancer Prevention Study II Nutrition Cohort. Cancer Epidemiol Biomarkers Prev 2004, 13:2187-2195.

35. Cottet V, Bonithon-Kopp C, Kronborg O, Santos L, Andreatta R, BoutronRuault MC, Faivre J: Dietary patterns and the risk of colorectal adenoma recurrence in a European intervention trial. Eur J Cancer Prev 2005 14:21-29.

36. Gunter MJ, Leitzmann MF: Obesity and colorectal cancer: epidemiology, mechanisms and candidate genes. J Nutr Biochem 2006, 17:145-156.

37. Orio F, Palomba S, Cascella T, Milan G, Mioni R, Pagano C, Zullo F, Colao A, Lombardi G, Vettor R: Adiponectin levels in women with polycystic ovary syndrome. J Clin Endocrinol Metab 2003, 88:2619-2623.

38. Yang WS, Tsou PL, Lee WJ, Tseng DL, Chen CL, Peng CC, Lee KC, Chen MJ, Huang CJ, Tai TY, Chuang LM: Allele-specific differential expression of a common adiponectin gene polymorphism related to obesity. J Mol Med 2003, 81:428-434.

39. Carvajal-Carmona LG, Spain S, Kerr D, Houlston R, Cazier JB, Tomlinson I: Common variation at the adiponectin locus is not associated with colorectal cancer risk in the UK. Hum Mol Genet 2009, 18:1889-1892.
40. Fujisawa $T$, Endo H, Tomimoto A, Sugiyama M, Takahashi H, Saito S, Inamori M, Nakajima N, Watanabe M, Kubota N, Yamauchi T, Kadowaki T, Wada K, Nakagama H, Nakajima A: Adiponectin suppresses colorectal carcinogenesis under the high-fat diet condition. Gut 2008, 57:1531-1538.

41. Ong KL, Li M, Tso AW, Xu A, Cherny SS, Sham PC, Tse HF, Lam TH, Cheung BM, Lam KS: Association of genetic variants in the adiponectin gene with adiponectin level and hypertension in Hong Kong Chinese. Eur J Endocrinol 2010, 163:251-257.

42. Otake S, Takeda H, Suzuki Y, Fukui T, Watanabe S, Ishihama K, Saito T, Togashi H, Nakamura T, Matsuzawa Y, Kawata S: Association of visceral fat accumulation and plasma adiponectin with colorectal adenoma: evidence for participation of insulin resistance. Clin Cancer Res 2005, 11:3642-3646.

43. Wang Y, Zhang D, Liu Y, Yang Y, Zhao T, Xu J, Li S, Zhang Z, Feng G, He L, $\mathrm{Xu}$ H: Association study of the single nucleotide polymorphisms in adiponectin-associated genes with type 2 diabetes in Han Chinese. Genet Genomics 2009, 36:417-423.

44. Psaty BM, Lumley T, Furberg CD: The metabolic syndrome: time for a critical appraisal: joint statement from the American Diabetes Association and the European Association for the Study of Diabetes: response to Kahn et al. Diabetes Care 2006, 29:177, author reply 177-178,

45. Siitonen N, Pulkkinen L, Mager U, Lindstrom J, Eriksson JG, Valle TT, Hamalainen H, llanne-Parikka P, Keinanen-Kiukaanniemi S, Tuomilehto J, Laakso M, Uusitupa M: Association of sequence variations in the gene encoding adiponectin receptor 1 (ADIPOR1) with body size and insulin levels. The Finnish Diabetes Prevention Study. Diabetologia 2006, 49:1795-1805.

46. Byeon JS, Jeong JY, Kim MJ, Lee SM, Nam WH, Myung SJ, Kim JG, Yang SK, $\mathrm{Kim} \mathrm{JH}$, Suh DJ: Adiponectin and adiponectin receptor in relation to colorectal cancer progression. Int J Cancer 2010.

\section{Pre-publication history}

The pre-publication history for this paper can be accessed here: http://www.biomedcentral.com/1471-2350/12/94/prepub

doi:10.1186/1471-2350-12-94

Cite this article as: He et al.: Effects of genetic variations in the Adiponectin pathway genes on the risk of colorectal cancer in the Chinese population. BMC Medical Genetics 2011 12:94.

\section{Submit your next manuscript to BioMed Central and take full advantage of:}

- Convenient online submission

- Thorough peer review

- No space constraints or color figure charges

- Immediate publication on acceptance

- Inclusion in PubMed, CAS, Scopus and Google Scholar

- Research which is freely available for redistribution

Submit your manuscript at www.biomedcentral.com/submit
C BioMed Central 